\title{
sciendo
}

\section{Evidence for the Relative Age Effect in the Spanish Professional Soccer League}

\author{
by \\ José María Yagüe ${ }^{1}$, Olga Molinero ${ }^{1}$, José Ángel Alba ${ }^{1}$, Juan Carlos Redondo
}

The concept of the relative age effect refers to the consequences of the physical and psychological differences that may exist between those born earlier or later within the same calendar year. The objective of the present study was to examine this phenomenon in Spanish professional soccer, identifying the influences of the competitive level and the club of origin. The sample comprised 2,130 individuals from five competitive categories: under 12 (U12; $n=480$ ), under 14 (U14; $n=338)$, under $16(U 16 ; n=390)$, under 19 years old $(U 19 ; n=489)$ and professional players $(n=$ 433), with nine teams from the Spanish professional soccer league (PSL). Statistical analysis was based on a chisquared test followed by calculation of the odds ratios and 95\% confidence intervals. The main results show that at all levels of competition there was over-representation of individuals born in the first few months of the year. By clubs, the same over-representation was observed. It may be concluded that the relative age effect is consistent and exists throughout Spanish soccer, whether at youth or professional levels. An analysis by age categories showed a more pronounced effect in those competitions in which the youngest players participate, while in clubs the effect continued to be significantly present in all cases investigated in the study.

Key words: birth quarter, talent identification, potential, team sport games.

\section{Introduction}

Grouping individuals by age is a frequent and proven technique in certain areas within society (contexts such as schools, sports or medicine). In youth soccer competitions, players are put into groups as a function of their chronological age in bands of two or three years. In 1997 the Fédération Internationale de Football Association (FIFA) established the $1^{\text {st }}$ January as a cut-off date, using the standard twelve-month calendar for groupings. This decision had the aim of guaranteeing the maximum equality of opportunities for players in diverse competitive contexts. However, it suffers from the weakness of not taking into account the age of maturation (Helsen et al., 2005; Malina et al., 2004). Individuals do not all undergo the process of maturing at the same rhythm, so that it can be said that maturation has a significant impact on sports careers of given subjects (Torres-Unda et al., 2013). Differences of up to twelve months occurring within groupings are what is known as the relative age, and their consequences constitute what is called the relative age effect (RAE) (Campbell, 2013; Dixon et al., 2011; Gutierrez Diaz Del Campo et al., 2010).

Studies of the RAE in a sports context had their origins in similar research in the field of education (Hurley et al., 2001). Here, there have been various investigations assessing the impact of the RAE in educational contexts, among the variables considered by them being academic achievement (Bedard and Dhuey, 2006), leadership (Dhuey and Lipscomb, 2008), and physical education and school sport (Cobley et al., 2008). On these lines, the earliest studies in the context of sport were the pieces of research undertaken by Grondin et al. (1984) with Canadians playing ice-hockey and volleyball, and by Barnsley et al. (1985), with ice-hockey players

1 - Department of Movement and Sports Sciences, University of Leon, Leon, Spain. 
in Canada. These noted a high percentage of players born in the first three months of the year.

Since then, there has been a wide range of research into a variety of sports in which the RAE has been the main variable investigated. Thus, with regard to volleyball, there was a study by Caamaño et al. (2016). This looked at a sample of world-standard and under-19 (U19) players, and noted that the relative age effect in both competitive categories gradually became less evident as the category increased. However, Nakata and Sakamoto (2012) found no significant differences regarding the RAE in males in the VLeague, although there were such in women, something which they attributed to the popularity of volleyball among females. In the area of athletics, Romann and Cobley (2015) studied the relative age effect in 7,761 male athletes aged between eight and fifteen engaged in $60 \mathrm{~m}$ sprinting in Switzerland. They proposed several promising corrective adjustments intended to eliminate the RAE. In handball, Schorer et al. (2009) undertook three studies which, among other matters, considered aspects linked to participation of the elite players, the position in which they played and their right- or lefthandedness. Finally, with respect to basketball, Saavedra-García et al. (2016) conducted investigations which did not concentrate, as is common, on just one year or just one season, but included an extensive sample from the World Championships of the International Basketball Association (FIBA) from 1979 to 2011, considering the birth dates of 3,699 players (1,975 male and 1,724 female) who participated in the categories of under 17 (U17), under 19 (U19) and under 21 years old (U21).

At this point, it should be observed that studies linking the RAE to sport have investigated a range of different variables such as individual performances of players, nationality, the position played in a team, team classifications, and the team category (Arrieta et al., 2016; Augste and Lames, 2011; Delorme et al., 2009; Lesma et al., 2011; Vaeyens et al., 2005). This research into soccer may be split between two contexts of application: men's and women's soccer, while also looking at several of its dimensions (elite professional soccer in national leagues, elite professional soccer of national teams, soccer of lower categories). Thus, there have been studies concentrated on men's professional soccer in Belgium (Helsen et al., 2005; Vaeyens et al., 2005), Germany (Augste and Lames, 2011; Cobley et al., 2008), Australia (Van den Honert, 2012), Turkey (Mulazimoglu, 2014), Norway (Wiium et al., 2010) and Spain (Gutierrez Diaz Del Campo et al., 2010). Likewise, there are also studies looking at the leagues in various countries, such as the work by Salinero et al. (2013), which took a sample of 2,763 players from the leagues of the United Kingdom, Germany, Italy, France and Spain and corroborated the presence of the RAE in soccer players from these professional leagues. Another investigation was undertaken by Padrón-Cabo et al. (2016), who studied the size of the RAE in 12,144 professional soccer players with various different variables (position, leagues where they played, competition level and nationality). They included subjects from fifteen professional leagues associated with FIFA (First and Second Divisions) during the 2014-2015 season. They found the RAE in all the leagues considered, except in the English Premier League and in the K-League Classic in South Korea.

Focusing on training categories of soccer, it may be noted that some research shows the RAE in this context (Bidaurrazaga-Letona et al., 2014; Glamser and Vincent, 2004; Mulazimoglu, 2014; Sæther, 2016; Williams, 2010). Another study undertaken by Helsen et al. (2005) with 2175 players from national selections of the competitive categories U21, U18, U16 and U15 and players from clubs of the competitive categories U14 and U12 indicated the presence of the RAE in national teams of Denmark, Belgium, England, France, Italy, Holland, Spain and Sweden. The greatest difference between those born in the first and the last quarter of the year was found in the selection of Germany (50.59\% in the first quarter and 3.89\% in the last quarter). In the same context, Augste and Lames (2011) not only verified the existence of the RAE in the sub-17 category of German elite soccer, but also related the RAE with the potential of sporting success of a team.

Although the relative age effect is a topic that has been extensively studied, there appears to be little research looking at the RAE that brings together all the male age categories (U12, U14, U16, U19 and professional). These make up the sporting structure of professional soccer clubs in a specific country, in this case Spain. Hence, the 
objective of this study was to determine the presence of the RAE in men's professional soccer clubs in Spain of an international level during the 2015-2016 season, looking both at their teams in youth categories and at those playing professionally. It was also intended to verify any possible differences in the RAE found in soccer teams at particular age levels (U12, U14, U16, U19), as opposed to professionals from the clubs investigated.

\section{Methods}

In order to evaluate the impact of the RAE on Spanish soccer, a register was drawn up of all the players in the various clubs in the Spanish Professional Soccer League during the 2015-2016 season. The information used in this research was obtained from the official websites of the different clubs considered. The study was performed in a manner that respected the principles established by the Declaration of Helsinki and approved by the Ethics Committee of the University.

\section{Sample}

Data for a total of 2,130 soccer players holding licences from the Spanish Royal Soccer Federation (RFEF) were entered into a database created specifically for the purposes of the present study. Data were obtained from 9 of the 20 clubs in the Spanish Professional Soccer League during the 2015-2016 season that made information available.

Table 1 shows the final distribution of players as a function of their falling into one of the five competitive categories: under 12 (U12; $\mathrm{n}=$ $480)$, under $14(\mathrm{U} 14 ; \mathrm{n}=338)$, under $16(\mathrm{U} 16 ; \mathrm{n}=$ 390), under $19(\mathrm{U} 19 ; \mathrm{n}=489)$ and professionals $(\mathrm{PRO} ; \mathrm{n}=433)$ of the nine teams from the Spanish Professional Soccer League (PSL). They were further divided on the basis of their dates of birth in accordance with the quarters of the year: Q1 (January, February and March), Q2 (April, May and June), Q3 (July, August and September), and Q4 (October, November and December). They were also distributed by the club of origin and the league in which a club's professionals play.

Expected birth date distributions were calculated for the available Spanish population birth statistics between 1980 and 2005 (Source: Spanish National Institute of Statistics, Madrid), in accordance with the birth range of the population targeted.

\section{Statistical Analysis}

Data analysis was carried out using the Statistical Package for Social Sciences (SPSS 24.0). To assess the presence of differences between the distributions of birth dates observed and those expected a chi squared $\left(\chi^{2}\right)$ test was used with degrees of freedom (df) on the basis of the categories under study. It was assumed that their distribution should be similar to that of the quarters of the year (Campos et al., 2017; Cobley; et al., 2009; Helsen et al., 2005). To evaluate the relevance of the differences between groups, the Cramér's $\mathrm{V}$ test was used, with values for $\mathrm{V}$ between 0.06 and 0.17 deemed a small effect, between 0.18 and 0.29 a medium effect, and greater than 0.30 a large effect (Cramér, 2016). When the test revealed the existence of statistically significant differences, the odds ratios and $95 \%$ confidence intervals were calculated, the reference datum being in all circumstances the distribution of those born in the first quarter. The greater the odds ratio, the greater was the likelihood that players had been born in the quarter assessed, in comparison with the reference. The level of significance was always set at $p<0.05$.

\section{Results}

Table 2 shows the distributions of births per quarter for the five subgroups. The chi squared $\left(\chi^{2}\right)$ analyses showed that the distributions of birth dates for all the groups of soccer players were significantly different $\left(\mathrm{V}_{\text {total }}=0.546 ; p=0.00\right)$. Q1 and Q2 were generally over-represented, as may be seen in Figure 1. Furthermore, Table 2 displays the results for odds ratios and the $95 \%$ confidence intervals (CIs), according to the competition category. Consideration of the results obtained by quarters allows to indicate that the odds ratios increased as the first quarter was compared with more distant quarters, especially the last (Q4), with the odds ratio for comparisons of Q1 and Q4 being the highest in all categories.

Table 3 shows that there were also significant differences in the distribution of birth quarters as a function of the grouping, taking into account two groups: youth soccer and professional soccer. All the same, subjects born in Q1 were more numerous in both subgroups. 
Table 1

Number of Players Categorized by Teams (frequency, fr)

\begin{tabular}{cccccc}
\hline \multirow{2}{*}{ TEAMS - PSL } & U12 & U14 & U16 & U19 & PRO \\
\hline T-1 & 60 & 37 & 42 & 41 & 46 \\
T-2 & 41 & 40 & 44 & 47 & 49 \\
T-3 & 61 & 44 & 43 & 68 & 52 \\
T-4 & & 45 & 45 & 59 & 59 \\
T-5 & 118 & 44 & 36 & 56 & 44 \\
T-6 & & & 45 & 40 & 42 \\
T-7 & 60 & 45 & 45 & 70 & 50 \\
T-8 & 89 & 46 & 50 & 68 & 48 \\
T-9 & 51 & 37 & 40 & 40 & 43 \\
n (categories) & $\mathbf{4 8 0}$ & $\mathbf{3 3 8}$ & $\mathbf{3 9 0}$ & $\mathbf{4 8 9}$ & $\mathbf{4 3 3}$ \\
\multicolumn{2}{c}{ T= Team; PSL = Professional Soccer League }
\end{tabular}

Table 2

Distribution of Birth Quarters (frequencies as percentages, fr \%) as a Function of the Competition Category of Players $(n=2,130)$ and for the Spanish General Population.

\begin{tabular}{|c|c|c|c|c|c|c|c|c|c|c|c|}
\hline \multirow[b]{2}{*}{ Category } & \multicolumn{9}{|c|}{ QUARTER } & \multicolumn{2}{|c|}{$\begin{array}{c}\text { Odds Ratio }(C I= \\
95 \%)\end{array}$} \\
\hline & Q1 & Q2 & Q3 & $Q 4$ & Total & & & & & & \\
\hline & $\begin{array}{l}f r \\
(\%)\end{array}$ & $\begin{array}{l}f r \\
(\%)\end{array}$ & $\begin{array}{l}f r \\
(\%)\end{array}$ & $\begin{array}{c}f r \\
(\%)\end{array}$ & $\begin{array}{c}f r \\
(\%)\end{array}$ & $X^{2}$ & $\mathrm{df}$ & $p$ & $V$ & Q1 vs. & Q2 vs. \\
\hline Total & $\begin{array}{c}930 \\
(43.7)\end{array}$ & $\begin{array}{c}634 \\
(29.8)\end{array}$ & $\begin{array}{c}363 \\
(17.0)\end{array}$ & $\begin{array}{l}203 \\
(9.5)\end{array}$ & $\begin{array}{c}2,130 \\
(100.0)\end{array}$ & 633.97 & 3 & .000 & .546 & & \\
\hline U12 & $\begin{array}{c}240 \\
(50.0)\end{array}$ & $\begin{array}{c}139 \\
(29.0)\end{array}$ & $\begin{array}{c}71 \\
(14.8)\end{array}$ & $\begin{array}{c}30 \\
(6.3)\end{array}$ & $\begin{array}{c}480 \\
(100.0)\end{array}$ & 210.52 & 3 & .000 & .662 & $\begin{array}{c}8.00 \\
(7.85 \\
\text { to } \\
8.16)\end{array}$ & $\begin{array}{c}4.63 \\
(4.57 \text { to } \\
4.70)\end{array}$ \\
\hline U14 & $\begin{array}{c}139 \\
(41.1)\end{array}$ & $\begin{array}{c}105 \\
(31.1)\end{array}$ & $\begin{array}{c}61 \\
(18.0)\end{array}$ & $\begin{array}{c}33 \\
(9.8)\end{array}$ & $\begin{array}{c}338 \\
(100.0)\end{array}$ & 78.05 & 3 & .000 & .481 & $\begin{array}{c}4.21 \\
(4.06 \\
\text { to } \\
4.37)\end{array}$ & $\begin{array}{c}3.18 \\
(3.10 \text { to } \\
3.28)\end{array}$ \\
\hline U16 & $\begin{array}{c}206 \\
(52.8)\end{array}$ & $\begin{array}{c}95 \\
(24.4)\end{array}$ & $\begin{array}{c}62 \\
(15.9)\end{array}$ & $\begin{array}{c}27 \\
(6.9)\end{array}$ & $\begin{array}{c}390 \\
(100.0)\end{array}$ & 184.71 & 3 & .000 & .688 & $\begin{array}{c}7.63 \\
(7.47 \\
\text { to } \\
7.80)\end{array}$ & $\begin{array}{c}3.52 \\
(3.47 \text { to } \\
6.57)\end{array}$ \\
\hline U19 & $\begin{array}{c}195 \\
(39.9)\end{array}$ & $\begin{array}{c}166 \\
(33.9)\end{array}$ & $\begin{array}{c}85 \\
(17.4)\end{array}$ & $\begin{array}{c}43 \\
(8.8)\end{array}$ & $\begin{array}{c}489 \\
(100.0)\end{array}$ & 121.68 & 3 & .000 & .499 & $\begin{array}{c}4.535 \\
(4.43 \\
\text { to } \\
4.65)\end{array}$ & $\begin{array}{c}3.860 \\
(3.78 \text { to } \\
3.95)\end{array}$ \\
\hline Professional & $\begin{array}{c}150 \\
(34.6)\end{array}$ & $\begin{array}{c}129 \\
(29.8)\end{array}$ & $\begin{array}{c}84 \\
(19.4)\end{array}$ & $\begin{array}{c}70 \\
(16.2)\end{array}$ & $\begin{array}{c}433 \\
(100.0)\end{array}$ & 39.03 & 3 & .000 & .300 & $\begin{array}{c}2.143 \\
(2.06 \\
\text { to } \\
2.23)\end{array}$ & $\begin{array}{c}1.843 \\
(1.79 \text { to } \\
1.90)\end{array}$ \\
\hline $\begin{array}{c}\text { Spanish } \\
\text { population }\end{array}$ & $\begin{array}{c}2,709,154 \\
(24.4)\end{array}$ & $\begin{array}{c}2,798,548 \\
(25.2)\end{array}$ & $\begin{array}{c}2,837,244 \\
\quad(25.6)\end{array}$ & $\begin{array}{l}2,758,851 \\
\quad(24.5)\end{array}$ & $\begin{array}{c}11,103,797 \\
(100.0)\end{array}$ & 3.25 & 3 & .355 & .017 & $\begin{array}{c}0.982 \\
(0.971 \\
\text { to } \\
0.993)\end{array}$ & $\begin{array}{c}1.014 \\
(1.006 \\
\text { to } \\
1.023)\end{array}$ \\
\hline
\end{tabular}

$X^{2}=$ chi squared, $d f=$ degrees of freedom, $p=$ level of significance, $V=$ Cramér's $V$ Test,$C I=$ Confidence Interval 
Table 3

Distribution of Birth Quarters (frequency as a percentage, fr \%) as a Function of Youth and Professional Levels in Soccer Players $(n=2,130)$.

\begin{tabular}{|c|c|c|c|c|c|c|c|c|c|c|c|}
\hline \multirow[b]{2}{*}{ Category } & \multicolumn{9}{|c|}{ QUARTER } & \multicolumn{2}{|c|}{ Odds Ratio (CI 95\%) } \\
\hline & $\begin{array}{c}\text { Q1 } \\
f r \\
(\%) \\
\end{array}$ & $\begin{array}{c}22 \\
f r \\
(\%)\end{array}$ & $\begin{array}{c}Q 3 \\
f r \\
(\%) \\
\end{array}$ & $\begin{array}{c}Q 4 \\
f r \\
(\%) \\
\end{array}$ & $\begin{array}{c}\text { Total } \\
f r \\
(\%)\end{array}$ & $X^{2}$ & $d f$ & $p$ & V & Q1 vs. Q4 & $Q 2$ vs. Q4 \\
\hline Total & $\begin{array}{c}930 \\
(43.7)\end{array}$ & $\begin{array}{c}634 \\
(29.8)\end{array}$ & $\begin{array}{l}363 \\
(17)\end{array}$ & $\begin{array}{c}203 \\
(9.5)\end{array}$ & $\begin{array}{l}2130 \\
(100)\end{array}$ & 602.381 & 3 & .000 & .532 & & \\
\hline Youth & $\begin{array}{l}780 \\
(46)\end{array}$ & $\begin{array}{c}505 \\
(29.8)\end{array}$ & $\begin{array}{c}279 \\
(16.4)\end{array}$ & $\begin{array}{c}133 \\
(16.2)\end{array}$ & $\begin{array}{l}1697 \\
(100)\end{array}$ & 563.354 & 3 & .000 & .576 & $\begin{array}{c}5.87 \\
(5.83 \text { to } 5.90)\end{array}$ & $\begin{array}{c}3.80 \\
(3.78 \text { to } 3.82)\end{array}$ \\
\hline Professional & $\begin{array}{c}150 \\
(34.6)\end{array}$ & $\begin{array}{c}129 \\
(29.8)\end{array}$ & $\begin{array}{c}84 \\
(19.4)\end{array}$ & $\begin{array}{c}70 \\
(9.5)\end{array}$ & $\begin{array}{c}433 \\
(100)\end{array}$ & 39.028 & 3 & .000 & .300 & $\begin{array}{c}2.14 \\
(2.063 \text { to } 2.23)\end{array}$ & $\begin{array}{c}1.843 \\
(1.79 \text { to } 1.90)\end{array}$ \\
\hline
\end{tabular}

$X^{2}=$ chi squared, $d f=$ degrees of freedom, $p=$ level of significance, $V=$ Cramér's $V$ Test,$C I=$ Confidence Interval

Table 4

Distribution of Birth Quarters (frequency as a percentage, fr. \%) as a Function of Players' Soccer Clubs $(n=2,130)$.

\begin{tabular}{|c|c|c|c|c|c|c|c|c|c|c|c|}
\hline \multirow{2}{*}{ Team } & \multicolumn{9}{|c|}{ QUARTER } & \multicolumn{2}{|c|}{$\begin{array}{c}\text { Odds Ratio } \\
\text { (CI 95\%) }\end{array}$} \\
\hline & $\begin{array}{c}Q 1 \\
f r(\%)\end{array}$ & $\begin{array}{c}\text { Q2 } \\
f r(\%)\end{array}$ & $\begin{array}{c}Q 3 \\
f r(\%)\end{array}$ & $\begin{array}{c}Q 4 \\
f r(\%)\end{array}$ & $\begin{array}{l}\text { Total } \\
\operatorname{Fr}(\%)\end{array}$ & $X^{2}$ & $D f$ & $P$ & $V$ & Q1 vs. Q4 & Q2 vs. Q4 \\
\hline$T-1$ & 97 (42.9) & $77(34.1)$ & 36 (15.6) & $\begin{array}{c}16 \\
(7.1)\end{array}$ & $226(100)$ & 72.938 & 3 & .000 & .568 & $\begin{array}{c}6.06 \\
(5.78 \text { to } 6.36)\end{array}$ & $\begin{array}{c}4.81 \\
(4.61 \text { to } 5.02)\end{array}$ \\
\hline$T-2$ & 99 (44.8) & $64(29)$ & 33 (14.9) & $25(11.3)$ & $221(100)$ & 61.552 & 3 & .000 & .528 & $\begin{array}{c}3.96 \\
\text { (3.79 to } 4.14)\end{array}$ & $\begin{array}{c}2.56 \\
\text { (2.49 to } 2.64)\end{array}$ \\
\hline$T-3$ & $\begin{array}{c}116 \\
(43.3)\end{array}$ & $82(30.6)$ & 49 (18.3) & $21(7.8)$ & $268(100)$ & 75.612 & 3 & .000 & .531 & $\begin{array}{c}5.52 \\
\text { (5.29 to } 5.77)\end{array}$ & $\begin{array}{c}3.91 \\
\text { (3.77 to } 4.05)\end{array}$ \\
\hline$T-4$ & $82(39.4)$ & $61(29.3)$ & $43(20.7)$ & $22(10.6)$ & $208(100)$ & 37.731 & 3 & .000 & .426 & $\begin{array}{c}3.73 \\
(3.48 \text { to } 3.99)\end{array}$ & $\begin{array}{c}2.77 \\
\text { (2.63 to } 2.92)\end{array}$ \\
\hline$T-5$ & $\begin{array}{c}148 \\
(49.7)\end{array}$ & 86 (28.9) & 43 (14.4) & $\begin{array}{l}21 \\
(7)\end{array}$ & $298(100)$ & 126.027 & 3 & .000 & .650 & $\begin{array}{c}7.05 \\
(6.84 \text { to } 7.27)\end{array}$ & $\begin{array}{c}4.10 \\
(4.01 \text { to } 4.19)\end{array}$ \\
\hline$T-6$ & $50(39.4)$ & 38 (29.9) & 21 (16.5) & $18(14.2)$ & $127(100)$ & 21.315 & 3 & .000 & .410 & $\begin{array}{c}2.78 \\
(2.53 \text { to } 3.05)\end{array}$ & $\begin{array}{c}2.11 \\
(1.97 \text { to } 2.26)\end{array}$ \\
\hline$T-7$ & $116(43)$ & $74(27.4)$ & 58 (21.5) & $\begin{array}{c}22 \\
(8.1)\end{array}$ & $270(100)$ & 67.481 & 3 & .000 & .500 & $\begin{array}{c}5.27 \\
(5.02 \text { to } 5.53)\end{array}$ & $\begin{array}{c}3.36 \\
\text { (3.25 to } 3.49)\end{array}$ \\
\hline$T-8$ & $\begin{array}{c}140 \\
(46.5)\end{array}$ & 83 (27.6) & $\begin{array}{c}45 \\
(15)\end{array}$ & $\begin{array}{c}33 \\
(11)\end{array}$ & 301 (100) & 92.395 & 3 & .000 & .554 & $\begin{array}{c}4.24 \\
(4.11 \text { to } 4.37)\end{array}$ & $\begin{array}{c}2.52 \\
(2.47 \text { to } 2.57)\end{array}$ \\
\hline$T-9$ & $82(38.9)$ & 69 (32.7) & 35 (16.6) & $25(11.8)$ & $211(100)$ & 41.796 & 3 & .000 & .445 & $\begin{array}{c}3.28 \\
\text { (3.10 to } 3.47)\end{array}$ & $\begin{array}{c}2.76 \\
\text { (2.63 to } 2.90)\end{array}$ \\
\hline
\end{tabular}

$X^{2}=$ chi squared,$d f=$ degrees of freedom, $p=$ level of significance, $V=$ Cramér's $V$ Test,$C I=$ Confidence Interval 


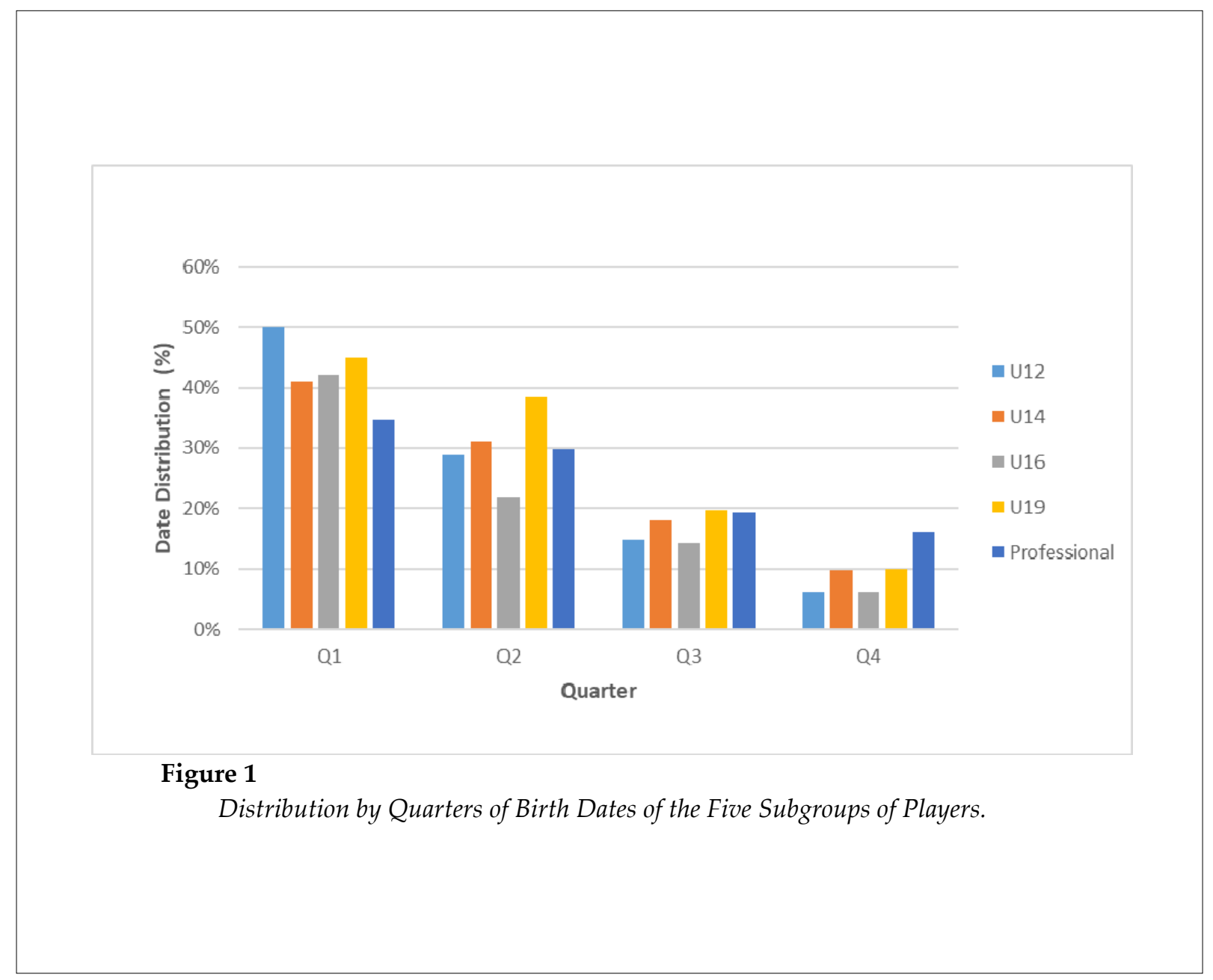

Finally, Table 4 presents the differences between the various different teams considered in this study. It is possible to see once again that the relative age effect on each of the clubs investigated was large and significant.

\section{Discussion}

The objective of this research was to examine the relative age effect in the general context of Spanish men's soccer in the 2015-2016 season, starting from youth groups through to the elite professional game. It was also intended to check on possible differences with regard to the RAE between youth and professional levels of soccer, this topic being investigated in various different Spanish soccer clubs. The RAE is a phenomenon recorded in almost all men's sports, whether team or individual (Albuquerque et al., 2012; Barnsley et al., 1985; Schorer et al., 2011). The present research confirms the considerable persistence of this effect among players in the professional soccer leagues of a range of countries, for instance as shown by investigations undertaken in Belgium (Helsen et al., 2005; Vaeyens et al., 2005), Germany (Cobley et al., 2008), Australia (Van den Honert, 2012) and Spain (Padrón-Cabo et al., 2016).

As had been expected, the main findings of the current research corroborate the presence of the RAE, with some significant differences between the five subgroups or categories of Spanish men's soccer studied, showing overrepresentation of players born in the first semester of the year (Q1 and Q2, between January and June). Furthermore, the effect was most pronounced in competitions involving the youngest soccer players (U12 and U16) and became less evident as the competition category increased towards the professional level. Such a trend was also noted in other studies of soccer 
(Mujika et al., 2009) and in other team sports (Caamaño et al., 2016), including volleyball and basketball (Saavedra García et al., 2015). It would appear that the advantages of a physical, cognitive and emotional nature experienced by those born at the beginning of the year, as opposed to those born at its end, act as a differentiating element in talent identification, sometimes causing the possible potential of players who have not yet developed as much as their slightly older peers to be overlooked (Delorme et al., 2009).

These results concur with those from other studies of soccer investigating only a single given age category (Augste and Lames, 2011; Glamser and Vincent, 2004). They are also in agreement with research closer in its design to that undertaken here, exploring several competitive categories of soccer (Pérez Jiménez and Pain, 2008). A large number of researchers have concentrated on just one group as their object of study, thus that the work carried out with young soccer players by Helsen et al. (2005) is of particular interest. They included at 2,175 players, considering national teams in the U21, U18, U17, U16 and U15 categories during the 1999-2000 season and club players at U14 and U12 levels participating in two tournaments taking place in Belgium in the year 2000. Their results showed significant effects in the national teams of Denmark, Belgium, England, France, Germany, Italy, Holland, Spain and Sweden.

Findings considering youth versus professional soccer showed that in both groups there was a higher concentration of players born in the first quarter of the year, noticeable at a statistical level. The RAE was more pronounced in youth categories than among professionals, also the difference in the percentage between $\mathrm{Q} 1$ and Q4 was $29.8 \%$ in youth soccer and $25.1 \%$ in the professional category. Consideration of these data would lead to the conclusion that coaches' decision-making when selecting talents is based on anthropometric, physical and physiological variables intimately linked to the RAE, rather than on technical skills. There is a tendency to discriminate players born closed to the end of the year in favour of players born in the first few months of the year. It can be stated that soccer players with a higher relative age are more likely to be identified as "talented" due to the probable advantage gained from their physical and biological maturity relative to the slightly younger members of their peer group (Cobley et al., 2009; Malina et al., 2004; Wattie et al., 2008).

Nevertheless, Penna et al. (2015) demonstrated that elite Brazilian U13 soccer players showed no differences in results of testing of the reaction time and movement time when considering their birth semesters. While there does seem to be a present-day trend to select players born in the first few months of the year and having a noticeable physical development, the question still remains complex. It is possible to state that individuals with great talent can come to stand out under any circumstances, as noted by Ford et al. (2008) in their analysis of 180 athletes awarded prizes for their sporting achievements, and not affected by the RAE.

Additionally, the incidence of the RAE on various clubs affiliated to the PSL was considered. It was observed that the relative age effect was large and significant in every single club investigated. The results for this variable coincided with the outcomes noted by Bidaurrazaga-Letona et al. (2014). They researched male and female players from a Spanish professional soccer club and found evidence of over-representation of soccer players born at the beginning of the year in all age groups, confirming the presence of the RAE in the club, especially among the youngest players (U12). It may be that the current structure of soccer enhances the RAE because of the precocious onset of competition in soccer, leading to a need to identify talent very early in elite clubs (Gutierrez Diaz Del Campo et al., 2010; Wattie et al., 2008). Nonetheless, there are studies to be found which suggest that players born in the final months of the year eventually grow out of their initial physical disadvantage arising from the RAE and reach a level similar to those born early in the year as they come to the end of their process of maturing (Malina et al., 2004; Mujika et al., 2009; Vaeyens et al., 2005).

Talent identification is a very complex matter, since it must attempt to gain a glimpse of personal futures, always unforeseeable because of the multitude of circumstances, outside any real control, under which personal lives evolve, and which may change people's fates or destinies. Nonetheless, it seems inevitable that if any 
improvements in its procedures and results are to be achieved, there will be a need for actions cutting across boundaries. All the same, there is extensive academic literature investigating the incidence of the RAE in the selection of athletes that does also offer some solutions limiting the effect that could be adopted by coaches and sports institutions. With regard to sport in general, there is particular current relevance in the proposals made in the study by Hurley et al. (2001) of youth hockey in Canada, together with the work of Romann and Cobley (2015) on sprinters. For soccer, the sport particularly considered here, the academic literature has suggested several solutions that might mitigate the effect being analysed (Haycraft et al., 2018; Helsen et al., 2005; Padrón-Cabo et al., 2016; Sedano et al., 2015).

In this sense, Mann and Van Ginneken (2017) undertook a promising experiment at the PSV Eindhoven soccer club in the Netherlands. A group of coaches observed a set of reduced-scale soccer matches on a modified pitch. Three groups of players were formed in the following way: (1) with no age information, (2) with details of players' date of birth given, and (3) with players wearing a shirt showing a number corresponding to each player's relative age (the eldest was number one, the youngest had the highest number issued). The results revealed a significant selection bias for the first two groups. Surprisingly, this bias was eliminated with the third group, with coaches watching matches in which they knew that the shirt number indicated the relative age of the player. Nevertheless, there is a need for prudence and further empirical work will be required to avoid any possible deficiencies in this strategy, such as prejudices that may arise by prior provision of such information to coaches. Conclusions

The results from the present study indicate that there is over-representation of players born in the first semester (Q1 and Q2) of the selection year, with a clear RAE in all the subgroups studied (U12, U14, U16, U19 and professional). This tendency becomes much less evident as categories increase from the lowest to the highest, i.e. professionals. Considering youth versus professional soccer, the RAE was significantly present in both groups. Finally, the study by clubs also showed significant differences arising from the RAE in all the clubs investigated.

\section{Practical Implications}

There is a significant relative age effect in the sports structures of soccer teams in Spain, and it is most prevalent in the youngest categories. Although several measures intended to limit the impact of the RAE based on suggestions provided in sports literature, it appears appropriate to stress the need to inform and sensitize sports institutions and coaches with regard to this phenomenon, to avoid as far as possible any overlooking or loss of talented players because they were born in the last few months of the year. It would also be helpful to give a different direction to competition, downplaying the importance of outcomes in the lowest categories, so as to work with a longer time horizon. Similarly, grouping by biological maturity (bone age, growth peaks, forecast height) might perhaps limit the effect considered.

\section{References}

Albuquerque MR, Lage GM, Costa VTd, Ferreira RM, Penna EM, Moraes LCCdA, Malloy-Diniz LF. Relative age effect in Olympic taekwondo athletes. Perceptual and Motor Skills, 2012; 114: 461-468

Arrieta H, Torres-Unda J, Gil SM, Irazusta J. Relative age effect and performance in the U16, U18 and U20 European Basketball Championships. J Sports Sci, 2016; 34: 1530-1534

Augste C, Lames M. The relative age effect and success in German elite U-17 soccer teams. J Sports Sci, 2011; 29: 983-987

Barnsley RH, Thompson AH. Barnsley PE. Hockey success and birthdate: The relative age effect. Can Assoc Health Phy Educ Recreation J, 1985; 51: 23-8

Bedard K, Dhuey E. The persistence of early childhood maturity: International evidence of long-run age effects. The Quarterly Journal of Economics, 2006; 121: 1437-1472 
Bidaurrazaga-Letona I, Lecue AB, Granados C, Lekue JA, Amado M, Gil SM. Relative age effect in soccer: a study in a professional Basque club. Retos: Nuevas Tendencias en Educación Física, Deporte y Recreación, 2014; 25: 95-99

Campbell T. In-school ability grouping and the month of birth effect. Preliminary evidence from the Millenium Cohort Study. London: Centre for Longitudinal Studies, 2013

Campos FA, Campos LC, Pellegrinotti, IL, Gómez MA. The Relative Age Effect in Soccer: an Analysis of the U20 Libertadores Cup. IJES, 2017; 10: 1157-1164

Cobley S, Baker J, Wattie N, McKenna J. Annual age-grouping and athlete development. Sports Med, 2009; 39: 235-256

Cobley S, Schorer J, Baker J. Relative age effects in professional German soccer: A historical analysis. J Sports Sci, 2008; 26: 1531-1538

Cramér H. Mathematical methods of statistics (PMS-9). New Jersey: Princeton university press; 2016

Delorme N, Boiché J, Raspaud M. The relative age effect in elite sport: the French case. Res Q Exercise Sport, 2009; 80: 336-344

Dhuey E, Lipscomb S. What makes a leader? Relative age and high school leadership. Econ Educ Rev, 2008; 27: 173-183

Dixon J, Horton S, Weir P. Relative age effects: Implications for leadership development. The International Journal of Sport and Society, 2011;2(2)

Ford PR, Webster A, Williams AM. Skill acquisition and expertise mediates the relative age effect in sport. J Sport Exerc Psychol, 2008; 30: S29-S30

Glamser FD, Vincent J. The Relative Age Effect Among Elite American Youth Soccer Players. J Sport Behav, 2004; 27: 31-38

Grondin S, Deshaies P, Nault LP. Quarters of birth and participation in hockey and volleyball. La Revue Québécoise de l'Activité Physique, 1984; 2: 97-103

Gutierrez Diaz Del Campo D, Vicedo P, Carlos J, Gonzalez Villora S, Jordan C, Ricardo O. The relative age effect in youth soccer players from Spain. J Sports Sci Med, 2010; 9: 190-198

Haycraft JA, Kovalchik S, Pyne DB, Larkin P, Robertson S. The influence of age-policy changes on the relative age effect across the Australian Rules football talent pathway. J Sci Med Sport, 2018; 21(10): 1106-1111

Helsen WF, Van Winckel J, Williams AM. The relative age effect in youth soccer across Europe. J Sports Sci, 2005; 23: 629-636

Hurley W, Lior D, Tracze S. A proposal to reduce the age discrimination in Canadian minor hockey. Can Public Pol, 2001; 27 65-75

Lesma M, Pérez-González B, Salinero JJ. Relative age affect (RAE) in Spanish Football League. JSHS, 2011; 3: 35-46

Iglesias M, Padrón A, García JL. Study of Relative Age Effect in players of Volleyball World Level. J Sport Health Res, 2016; 8: 163-172

Malina RM, Bouchard C, Bar-Or O. Growth, maturation, and physical activity. Champaign, Il.: Human kinetics; 2004

Mann DL, van Ginneken PJ. Age-ordered shirt numbering reduces the selection bias associated with the relative age effect. J Sports Sci, 2017; 35: 784-790

Mujika I, Vaeyens R, Matthys SP, Santisteban J, Goiriena J, Philippaerts R. The relative age effect in a professional football club setting. J Sports Sci, 2009; 27: 1153-1158

Mulazimoglu O. The relative age effect (RAE) in youth and professional soccer players in Turkey. The Anthropologist, 2014; 18: 391-398

Nakata H, Sakamoto K. Sex differences in relative age effects among Japanese athletes. Perceptual and motor skills, 2012; 115: 179-186

Padrón-Cabo A, Rey E, García-Soidán JL, Penedo-Jamardo E. Large scale analysis of relative age effect on professional soccer players in FIFA designated zones. Int J Perf Anal Spor, 2016; 16: 332-346

Penna EM, de Mello MT, Ferreira RM, Moraes, LCCdA, Costa VTd. Relative age effect on the reaction time of soccer players under 13 years old. Motriz: Revista de Educação Física, 2015; 21: 194-199 
Pérez Jiménez I, Pain MT. Relative age effect in Spanish association football: Its extent and implications for wasted potential. J Sports Sci, 2008; 26: 995-1003

Romann M, Cobley S. Relative age effects in athletic sprinting and corrective adjustments as a solution for their removal. PLoS One, 2015; 10: e0122988.

Saavedra García M, Gutiérrez Aguilar Ó, Galatti L, Fernández Romero JJ. Relative age effect in lower categories of fiba basketball world championships (1979-2011). Cuadernos de Psicología del Deporte, 2015; 15: $237-242$

Saavedra-García M, Gutiérrez-Aguilar O, Sa-Marques P, Fernández-Romero JJ. Relative age effect in Spanish athletics. Cuadernos de Psicología del Deporte, 2016; 16: 275-286

Salinero JJ, Pérez B, Burillo P, Lesma ML. Relative age effect in european professional football. Analysis by position. J. Hum. Sport Exerc, 2013; 8

Schorer J, Cobley S, Büsch D, Bräutigam H. Baker, J. Influences of competition level, gender, player nationality, career stage and playing position on relative age effects. Scand J Med Sci Spor, 2009; 19: 720730

Schorer J, Neumann J, Cobley SP, Tietjens M, Baker J. Lingering effects of relative age in basketball players' post athletic career. Int J Sports Sci Coa, 2011; 6: 143-147

Sedano S, Vaeyens R, Redondo JC. The Relative Age Effect in Spanish Female Soccer Players. Influence of the Competitive Level and a Playing Position. J Hum Kinet, 2015; 46: 129-137

Sæther SA. Presence of the relative age effect and its effect on playing time among under-20 players in the Norwegian premier league Tippeligaen-a four-year follow up. Montenegrin Journal of sports science and medicine, 2016; 5: 11-15

Torres-Unda J, Zarrazquin I, Gil J, Ruiz F, Irazusta A, Kortajarena M, Seco J, Irazusta J. Anthropometric, physiological and maturational characteristics in selected elite and non-elite male adolescent basketball players. J Sports Sci, 2013: 31: 196-203

Vaeyens R, Philippaerts R, Malina RM. The relative age effect in soccer: A match-related perspective. J Sports Sci, 2005; 20: 747-756

Van den Honert R. Evidence of the relative age effect in football in Australia. J Sports Sci, 2012; 30: 1365-1374

Vincent J, Glamser FD. Gender differences in the relative age effect among US Olympic Development Program youth soccer players. J Sports Sci, 2006; 24: 405-413

Wattie N, Cobley S, Baker J. Towards a unified understanding of relative age effects. J Sports Sci, 2008; 26: 1403-1409

Wiium N, Lie SA. Ommundsen Y, Enksen HR. Does relative age effect exist among Norwegian professional soccer players. International J. Appl Sports Sci, 2010; 22: 66-76

Williams J. Relative age effect in youth soccer: analysis of the FIFA U17 World Cup competition. Scand J Med Sci Spor, 2010; 20: 502-508

\section{Corresponding author:}

\section{Juan Carlos Redondo}

University of Leon

Faculty of Physical Education

Campus de Vegazana s/n

24071 - León. Spain

Phone: +34987293054

E-mail: jc.castan@unileon.es 